DOI: https://doi.org/10.47405/mjssh.v5i1.350

\begin{tabular}{|c|c|}
\hline $\begin{array}{c}\text { Malaysian Journal of } \\
\text { Social Sciences and } \\
\text { Humanites } \\
\text { (MJ - SSH) }\end{array}$ & Malaysian Journal of Social Sciences and Humanities (MJSSH) \\
& Volume 5, Issue 1, January 2020 \\
& e-ISSN : 2504-8562 \\
& Journal home page: \\
\hline
\end{tabular}

\title{
Penyertaan Wanita dalam Politik Parlimen Post-Soeharto di Indonesia
}

\author{
Yumasdaleni' ${ }^{1}$, Chan Kim Ling', Mimi Hanida Abdul Mutalib ${ }^{1}$ \\ 1Universiti Kebangsaan Malaysia (UKM)
}

Correspondence: Yumasdaleni (mediloka@yahoo.co.id)

\begin{abstract}
Abstrak
Artikel ini membincangkan tentang penyertaan wanita dalam pilihan raya di Indonesia setelah pentadbiran Presiden Soeharto. Penyertaan wanita dalam pilihan raya melalui isu kuota bermula pada tahun 2004. Pengumpulan data dengan cara kualitatif yang disokong data kuantitatif. Dokumen paper ini menjelaskan dua faktor dinamik dalam penyertaan wanita pada politik parlemen. Pertama faktor undang-undang dan polisi, kedua faktor parti politik dalam rekrutmen wanita. Hasil penyelidikan ini menjelaskan bahawa pilihan raya 2004, 2009, 2014, dan 2019 relatif meningkat jumlah bilangan wanita masuk parlemen. Hal ini disokong oleh perubahan undang-undang pilihan raya yang menyatakan bahwa wanita wajib disertakan dalam senarai calon sekurangnya $30 \%$ dan satu daripada tiga calon wajib ada wanita. Undang-undang ini adalah perubahan dari kata "cadangan" menjadi "wajib" dalam menetapkan calon. Ayat wajib itu menjadi penting dalam perubahan peningkatan bilangan wanita terpilih. Selain faktor undang-undang ada faktor parti kader yang menjadi catatan isu iaitu tidak maksimalnya parti dalam sistim rekrutmen. Kurangnya wanita parti kader yang cekap dalam politik menjadikan parti merekrut wanita segera pada masa pendaftaran calon. Wanita-wanita yang dipilih adalah mereka yang terkait dengan keluarga elit politik. Wanita yang datang dari elit politik ini dianggap berpeluang menang dalam pilihan raya kerana mereka mempunyai modal dan jaringan yang kuat. Keadaan ini juga sering menepikan wanita yang sudah lama aktif dalam parti tapi tidak cukup modal untuk kempen. Nombor satu dalam senarai calon di kertas undi menjadi penting kerana mereka yang terpilih pada tiap pilihan raya lebih dari limapuluh peratus namanya di nombor satu, isu ini yang juga sering menepikan wanita.
\end{abstract}

Kata kunci: penyertaan wanita, politik parlimen, post-Soeharto, Indonesia

\section{Women Participation in Political Parliement Post-Soeharto in Indonesia}

\begin{abstract}
This article discusses women's elections participation in Indonesia after President Soeharto's government. Women's participation in elections through quota issues began in 2004. Collecting data in a qualitative method and supported by quantitative data. This document describes two dynamic factors in women's participation in the political parliament. The first is the law and the policy factors, the second is the political party's factor in women's recruitment. The results of this study suggest that 2004, 2009, 2014, and 2019 elections have significantly increased the number of women entering parliament. This is supported by a change in the electoral law stating that women must be included in the list of at least $30 \%$ and one in three candidates must be women. This law is a change from the word "consideration" to "mandatory" in candidate lists. The obligatory passage has been crucial in the changing number of women selected. In addition factors in the cadre party that are the issue of the
\end{abstract}


party's inability to recruit systems. The lack of political party women cadre, the party recruits women instantly. The women chosen are those associated with the family of the political elite. Women who come from this political elite are eligible to be elected because they have strong capital and networking. This situation also often excludes women who have been active in the party but have insufficient funds for the campaign. The number one candidate on the ballot paper list is important as those who are elected in every election have more than fifty percent of their names in number one, which often excludes women.

Keywords: women participation, parliament, post-Soeharto, Indonesia

\section{Pengenalan}

Sistem demokrasi adalah sebagai wujud dari idea kedaulatan rakyat. Kedaulatan rakyat dengan sistem perwakilan parlimen dapat dicapai melalui pilihan raya. Untuk sampai kepada pelaksanaan pilihan raya diperlukan lembaga politik berjenama parti. Undang-undang 1945 sebagai dasar Negara Indonesia menyatakan bahawa institusi politik berfungsi sebagai pelaksana kedaulatan rakyat (Sanit 1997). Parti politik dapat mewujudkan nilai-nilai dan kepentingan masyarakat ke dalam sistim politik yang berlaku. Aspirasi daripada masyarakat sipil dapat disampaikan melalui parti politik.

Pilihan raya legislatif adalah untuk memilih wakil rakyat yang untuk duduk sebagai ahli parlimen. Parlimen adalah tempat yang mempunyai kuasa dalam penyelenggaran Negara dalam urusan perundangan (legislation) dan belanjawan (budgeting). Ahli parlimen seharusnya diisi oleh orang yang mewakili daripada unsur gender yang setara, mewakili kumpulan minority dan kumpulan lainnya yang berkepentingan terhadap pengubalan Undang-undang dan belanjawan Negara.

Struktur kuasa sangat dinamik dalam konteks sejarah pilihan raya di Indonesia. Sejak Indonesia merdeka pada 17 Agustus 1945 proses mendapatkan dan peralihan kuasa di Indonesia mengalami dinamik yang terhubung-kait dengan keberadaan wanita dalam politik kuasa tersebut. Keberadaan dan penyertaan wanita dalam politik juga berkaitan dengan konteks sosial budaya masyarakat yang berlaku pada masa tersebut.

Tahun 1998 bagi Indonesia adalah peristiwa penting dalam kepimpinan kerajaan. Presiden Soeharto yang telah memimpin Indonesia selama 32 (tiga puluh dua) tahun harus berhenti menjadi presiden kerana tuntutan masyarakat. Berhentinya Soeharto sebagai Presiden bukan pada masa yang ditetapkan oleh Majelis Permusyawaratan Rakyat (MPR). MPR menetapkan Soeharto sebagai Presiden untuk tempoh ketujuh (7) kalinya (1998-2003). Semenjak tahun 1966 sampai tahun 1998 Indonesia di bawah kepimpinan Soeharto.

Era post-Soeharto dikenal juga dengan era "Reformasi". Reformasi adalah jargon yang digunakan untuk menuntut perubahan dalam pelbagai aspek. Jargon utama yang disuarakan adalah menghentikan amalan "Korupsi, Kolusi dan Nepotisma" (KKN). Kerajaan di bawah kendali Presiden Soeharto telah menyuburkan amalan KKN sehingga merugikan masyarakat termasuk perempuan. Peranan perempuan yang digariskan dalam Garis Besar Haluan Negara (GBHN) dan Program Kesejahteraan Keluarga (PKK) telah meminggirkan wanita dari kawasan publik. Sistem Pilihan Raya dan Parti yang dikendalikan oleh Presiden Soeharto juga ikut menjejaskan peranan wanita di publik.

Kesedaran dari "wanita aktivis" yang ikut memulakan "unjuk perasaan" yang diberi nama "Suara Ibu Peduli" kepada Presiden Soeharto untuk turun dari kerusi Presiden diikuti oleh ramai masyarakat "civil" lainnya. Gerakan unjuk perasaan yang paling meluas dan lama oleh mahasiswa di banyak kawasan Indonesia. Unjuk perasaan telah memakan mangsa mahasiswa yang mati ditembak tentera kerajaan. Peristiwa ini disebut "Tragedi Mei 1998". Rangkaian (sequence) dari banyak unjuk perasaan adalah berakhirnya kepimpinan Soeharto sebagai Presiden pada 21hb Mei 1998. 
DOI: https://doi.org/10.47405/mjssh.v5i1.350

Setelah Presiden Soeharto berhenti pada bulan Mei 1998 kerajaan baru di bawah kepimpinan Presiden Habibie yang sebelumnya menjadi timbalan. Tuntutan rakyat kepada Presiden Habibie untuk melakukan "reformasi" dalam sistim "Tata Negara" disambut dengan Presiden Habibie bersama parlimen mengubal undang-undang Pemilu (Pilihan raya), Undang-undang Susunan dan Kedudukan Anggota (ahli) Dewan Perwakilan Rakyat, Majelis Permusyawaratan Rakyat dan Dewan Perwakilan Rakyat Daerah. Undang-undang ini sebagai dasar dan pelan untuk mengadakan pilihan raya yang baru untuk tahun 1999.

Pada masa Presiden Soekarno parti-parti dapat dikenali melalui "idiology" yang mereka perjuangkan. Komunis, Sosialis, Liberal dan Nasionalis adalah contoh daripada ideology party. Presiden Soeharto membuat polisi berkaitan dengan parti dengan membuat sistem satu Golkar, kedua PDI dan ketiga PPP. Parti yang sebelumnya ada harus masuk dalam tiga pilihan itu. "Ideology" yang dapat dibedakan adalah Golkar adalah parti kerajaan, PPP parti Islam dan PDI parti Nasionalis. Sistem parti yang muncul setelah pemerintah Soeharto seperti "party as office-seekers". Bentuk parti ini adalah kumpulan ahli politik persaingan (compettition) untuk mendapatkan kuasa untuk diri mereka sendiri (Soeseno 2014; 89).

Penjelasan tentang pilihan raya post-Soeharto yang bermula tahun 1999 kemudian 2004, 2009, dan 2014 adalah bilangan pilihan raya pada era demokrasi. Pada tahun 1999 pilihan raya pertama PostSoeharto dianggap bersifat terbuka, jujur dan adil. Melihat angka bilangan wanita yang terpilih pada pilihan raya era demokrasi ini bermaksud untuk melihat dinamik keberadaan wanita dalam politik parlimen.

\section{Pilihan Raya 1999-2019}

\section{Pilihan Raya Tahun 1999 (7 June 1999)}

Situasi Indonesia setelah Soeharto berhenti menjadi presiden pada Mei 1998 banyak mengalami perubahan dalam banyak aspek. Perubahan paling utama pada Undang-undang sistem struktur Negara, pilihan raya, parti politik dan Undang-undang susunan dan kedudukan DPR-MPR. Pilihan raya yang domokratik, jujur dan terbuka adalah tuntutan dari masyarakat Indonesia. Manakala masa Orde Baru yang ikut bertanding hanya Golkar, PPP dan PDI saja kemudian masa awal era reformasi ini menjadi 48 (empat puluh lapan) parti yang ikut bersaing dalam pilihan raya tahun 1999.

Sebanyak 48 parti yang bersaing untuk mendapatkan kerusi hasilnya ada 21 (dua puluh satu) parti yang berhasil mendapatkan kerusi parlimen. Dari 21 parti itu pula hanya 8 (lapan parti) yang mendapatkan wanita terpilih. Berikut jadual parti yang mendapatkan kerusi wanita yang masuk parlimen.

Jadual 1: Parti dan Wanita Parlemen 1999

\begin{tabular}{lllll}
\hline No & Parti Politik & Kerusi Parti & Kerusi Wanita & $\begin{array}{l}\text { Peratus Kerusi } \\
\text { Wanita }\end{array}$ \\
\hline 1 & PDI Perjuangan & 153 & 16 & $10.46 \%$ \\
2 & Golkar & 120 & 15 & $12.5 \%$ \\
3 & PKB & 51 & 4 & $7.84 \%$ \\
4 & PPP & 58 & 3 & $5.17 \%$ \\
5 & PAN & 34 & 1 & $2.94 \%$ \\
6 & Parti Bulan Bintang & 13 & 1 & $7.69 \%$ \\
7 & Parti Demokrasi Kasih Bangsa $\%$ \\
8 & Parti Keadilan & 5 & 1 & $20 \%$ \\
9 & PNU & 7 & 1 & $14.29 \%$ \\
10 & PKPI & 5 & &
\end{tabular}




\begin{tabular}{|c|c|c|c|c|}
\hline 11 & PDI & 2 & & \\
\hline 12 & PDU & 2 & & \\
\hline 13 & $\begin{array}{l}\text { Lain-lain parti (satu masing- } \\
\text { masing) }\end{array}$ & 8 & & \\
\hline 14 & Kerusi Tentra dan Polis & 38 & & \\
\hline \multicolumn{2}{|c|}{ Total 500} & 500 & 42 & $9.09 \%$ \\
\hline
\end{tabular}

Sumber: (Margret et al. 2018: 21)

Jadual di atas menunjukkan bahawa PDIP adalah yang paling ramai wanita masuk parlimen, meskipun begitu secara bilangan peratus PDKB adalah yang tertinggi iaitu 20\%. Pada pilihan raya tahun 1999 ini kerusi peruntukan khusus untuk ABRI masih ada iaitu 38 kerusi, sehingga total ahli parlimen pada period 1999-2004 adalah 500 kerusi.

\section{Pilihan Raya Tahun 2004 (5 April 2004)}

Jika pada pilihan raya tahun 1999 jumlah wanita masuk parlimen hanya $9.09 \%$ (peratus) dari total kerusi maka pada pilihan raya tahun 2004 ada peningkatan jumlah kerusi wanita. Jadual berikut adalah sebagai gambaran jumlah bilangan wanita yang masuk parlimen period 2004-2009.

Jadual 2: Jumlah kerusi wanita dari parti politik pada pilihan raya tahun 2004

\begin{tabular}{|c|c|c|c|c|}
\hline No & Parti Politik & Kerusi Parti & $\begin{array}{l}\text { Kerusi } \\
\text { Wanita }\end{array}$ & $\begin{array}{l}\text { Peratus } \\
\text { Kerusi } \\
\text { Wanita }\end{array}$ \\
\hline 1 & Golkar & 128 & 18 & $14 \%$ \\
\hline 2 & PDI Perjuangan & 109 & 12 & $11 \%$ \\
\hline 3 & PPP & 58 & 3 & $5.17 \%$ \\
\hline 4 & Demokrat & 55 & 6 & $10.9 \%$ \\
\hline 5 & PAN & 53 & 7 & $13.20 \%$ \\
\hline 6 & PKB & 52 & 7 & $13.46 \%$ \\
\hline 7 & PKS & 45 & 3 & $6.68 \%$ \\
\hline 8 & Parti Bintang Reformasi & 14 & 2 & $14.28 \%$ \\
\hline 9 & Parti Damai Sejahtera & 13 & 3 & $23.07 \%$ \\
\hline 10 & Parti Bulan Bintang & 11 & 0 & 0 \\
\hline 11 & $\begin{array}{l}\text { Parti Persatuan Demokrasi } \\
\text { Kebangsaan }\end{array}$ & 4 & 0 & 0 \\
\hline 12 & Parti Pelopor & 3 & 1 & $33.3 \%$ \\
\hline 13 & Parti Karya Peduli Bangsa & 2 & 0 & 0 \\
\hline 14 & Parti Penegak Demokrasi Indonesia & 1 & 0 & 0 \\
\hline 15 & $\begin{array}{l}\text { Parti Keadilan dan Persatuan } \\
\text { Indonesia }\end{array}$ & 1 & 0 & 0 \\
\hline 16 & PNI Marhaen & 1 & 0 & 0 \\
\hline \multicolumn{2}{|c|}{ Total } & 550 & 62 & $11.27 \%$ \\
\hline
\end{tabular}

Sumber: (Margret et al. 2018: 22)

Parti Golkar dan PDIP adalah penyumbang kerusi terbanyak dalam 2 (dua) pilihan raya. Undangundang tentang parti dan pilihan raya untuk pemilihan tahun 2004 ini banyak berubah dari Undang- 
undang sebelumnya. Ada beberapa isu yang mengemuka antaranya adalah UU keterwakilan minimam 30 peratus, isu Nombor dalam senarai calon, isu kawasan undi dengan kerusi bilangan besar dan kecil.

Polisi "Affirmative action" pertama dikenalkan melalui Undang-undang Nombor 31 tahun 2002 dan UU Nombor 12 tahun 2003 sebelum pilihan raya tahun 2004. Isi daripada polisi ini berupa "himbauan" (ajakan atau seruan) bagi parti politik untuk mencalonkan paling kurang 30\% (tiga puluh peratus) dalam pengurusi parti dan dalam senarai calon. Menurut Puskapol FISIP UI (2015) angka 30\% diambil dari jumlah minimam "critical mass" berdasarkan pada kajian United Nations Division for Advencement of Women (UN-DAW) menyatakan bahawa suara wanita dalam menunjuk dan memperjuangkan nilai-nilai, keutamaan (priority) dan karakter khas wanita baru diperhatikan publik apabila suaranya mencapai $30-35 \%$.

Dorongan "Affirmative action" masuk dalam Undang-undang adalah usaha daripada "Activist" wanita dengan melakukan pendekatan, "lobby" dan kempen kepada ahli DPR period 1999-2004. Meskipun belum mencapai hasil yang diharapkan namun pilihan raya tahun 2004 bilangan jumlah wanita sedikit meningkat daripada tahun 1999.

Isu nombor urut dalam senarai calon juga muncul dalam pilihan raya 2004 melalui Undang-undang Nombor 12 tahun 2003. Penentuan dan penetapan calon terpilih apabila setiap calon dalam satu parti tidak mencapai syarat 1 (satu) kerusi, namun jika digabung semua hasil undi untuk parti dan calon bilangnya cukup maka yang berhak mendapatkan kerusi itu adalah calon nombor 1 (satu). Peraturan ini dinilai merugikan calon termasuk wanita yang banyak berada di nombor urut bawah.

Bilangan kawasan undi pula menjadi isu yang diperbincangkan. Kajian daripada Margret (Margret et al. 2018) besarnya jumlah daerah dalam 1 (satu) kawasan pilihan ikut berpengaruh pada upaya wanita mendapatkan kerusi. Melihat pada perbandingan kawasan wanita yang terpilih di tahun 2004 da 2009 maka "Daerah Pemilihan" kecil lebih punya peluang wanita terpilih.

Sebagai gambaran dari bilangan kawasan undi pilihan raya tahun 2004 adalah 69 daerah pemilihan (kawasan), ini merujuk kepada ketetapan kawasan undi berasas kepada bilangan penduduk hasil banci di suatu kawasan provinsi (negri). Jika bilangan penduduk mencapai kurang dari 2 juta maka hanya satu sahaja kawasan undi untuk legislative DPR RI. Bilangan kerusi yang diundi sebanyak 3 (tiga) sampai 12 (dua belas). Ada provinsi yang hanya berebut 3 (tiga) kerusi sahaja seperti provinsi Kepulauan Riau, Bangka Belitung, Gorontalo, Maluku Utara dan Irian Jaya Barat. Berikut senarai jumlah kerusi dari masing-masing provinsi.

Jadual 3: Kawasan Undi dan Bilangan Kerusi

\begin{tabular}{llll}
\hline No & Provinsi & $\begin{array}{l}\text { Jumlah Kerusi } \\
\text { (Total) }\end{array}$ & $\begin{array}{l}\text { Kawasan Undi dan } \\
\text { Kerusi }\end{array}$ \\
\hline 1 & Nangroe Aceh Darussalam (NAD) & 13 kerusi & $\begin{array}{l}\text { NAD I }=7 \text { kerusi } \\
\text { NAD II }=6 \text { kerusi }\end{array}$ \\
& Sumatera Utara (Sumut) & 29 kerusi & $\begin{array}{l}\text { Sumut I }=10 \\
\text { Sumut II }=9\end{array}$ \\
& & & Sumut III $=10$ \\
& & Sumbar I $=8$ \\
3 & Sumatera Barat (Sumbar) & 14 kerusi & Sumbar II $=6$ \\
4 & Riau & Satu kawasan undi \\
5 & Kepulauan Riau & 11 kerusi & Satu kawasan undi \\
6 & Jambi & 3 kerusi & Satu kawasan undi \\
7 & Sumatera Selatan (Sumsel) & 7 kerusi & Sumsel I = 8 \\
& & 16 kerusi & Sumsel II = 8 \\
\hline
\end{tabular}



DOI: https://doi.org/10.47405/mjssh.v5i1.350

\begin{tabular}{|c|c|c|c|}
\hline 8 & Bangka Belitung & 3 kerusi & Satu kawasan undi \\
\hline 9 & Bengkulu & 4 kerusi & Satu kawasan undi \\
\hline 10 & Lampung & 17 kerusi & $\begin{array}{l}\text { Lampung } I=8 \\
\text { Lampung II }=9\end{array}$ \\
\hline 11 & Banten & 22 kerusi & $\begin{array}{l}\text { Banten } \mathrm{I}=11 \\
\text { Banten II = } 11\end{array}$ \\
\hline 12 & $\begin{array}{l}\text { Daerah Khusus Ibukota Jakarta (DKI } \\
\text { Jakarta) }\end{array}$ & 21 kerusi & $\begin{array}{l}\text { DKI I }=12 \\
\text { DKI II }=9\end{array}$ \\
\hline 13 & Jawa Barat & 90 kerusi & $\begin{array}{l}\text { Jabar I =6 } \\
\text { Jabar II }=10 \\
\text { Jabar III }=11 \\
\text { Jabar IV }=11 \\
\text { Jabar V }=12 \\
\text { Jabar VI }=6 \\
\text { Jabar VII }=9 \\
\text { Jabar VIII = } 8 \\
\text { Jabar IX }=7 \\
\text { Jabar X }=10\end{array}$ \\
\hline 14 & Jawa Tengah & 76 kerusi & $\begin{array}{l}\text { Jateng I }=8 \\
\text { Jateng II }=7 \\
\text { Jateng III }=9 \\
\text { Jateng IV }=6 \\
\text { Jateng V }=8 \\
\text { Jateng VI }=8 \\
\text { Jateng VII }=7 \\
\text { Jateng VIII }=8 \\
\text { Jateng IX }=8 \\
\text { Jateng X }=7\end{array}$ \\
\hline 15 & Jogjakarta & 8 kerusi & Satu kawasan undi \\
\hline 16 & Jawa Timur & 86 kerusi & $\begin{array}{l}\text { Jatim } I=10 \\
\text { Jatim II }=7 \\
\text { Jatim III }=7 \\
\text { Jatim IV }=8 \\
\text { Jatim V }=8 \\
\text { Jatim VI }=9 \\
\text { Jatim VII }=8 \\
\text { Jatim VIII }=10 \\
\text { Jatim IX }=11 \\
\text { Jatim X }=8\end{array}$ \\
\hline 17 & Bali & 9 kerusi & Satu kawasan undi \\
\hline 18 & Nusa Tenggara Barat & 10 kerusi & Satu kawasan undi \\
\hline 19 & Nusa Tenggara Timur & 13 kerusi & $\begin{array}{l}\text { NTT I }=6 \\
\text { NTT II }=7\end{array}$ \\
\hline 20 & Kalimantan Barat & 10 kerusi & Satu kawasan undi \\
\hline 21 & Kalimantan Selatan & 11 kerusi & Satu kawasan undi \\
\hline 22 & Kalimantan Tengah & 6 kerusi & Satu kawasan undi \\
\hline 23 & Kalimantan Timur & 7 kerusi & Satu kawasan undi \\
\hline 24 & Sulawesi Selatan & 24 kerusi & Sul Sel I = 12 \\
\hline
\end{tabular}




\begin{tabular}{llll}
\hline & & & Sul Sel II $=12$ \\
25 & Sulawesi Tenggara & 5 kerusi & Satu kawasan undi \\
27 & Sulawesi Tengah & 6 kerusi & Satu kawasan undi \\
28 & Gorontalo & 6 kerusi & Satu kawasan undi \\
29 & Maluku & 3 kerusi & Satu kawasan undi \\
30 & Maluku Utara & 4 kerusi & Satu kawasan undi \\
31 & Papua & 3 kerusi & Satu kawasan undi \\
32 & Papua Barat & 10 kerusi & Satu kawasan undi \\
& & 3 kerusi & Satu kawasan undi \\
\hline
\end{tabular}

Sumber: Komisi Pemilihan Umum. www.kpu.go.id

Kartawidjaja dan Pramono (Kartawidjaja and Pramono 2007) membagi tiga kumpulan kawasan undi kecil, sedang dan besar. Kumpulan kecil kerusi 3-5 ada 28 kerusi, kumpulan sedang 6-9 ada 397 kerusi dan kumpulan besar 10-12 ada 125 kerusi. Hasil daripada pilihan raya berasaskan pada kumpulan ini bilangan wanita terpilih pada kumpulan sedang dan besar kecenderungannya lebih tinggi berbanding kawasan undi kecil.

\section{Pilihan Raya 2009 (9 April 2009)}

Pilihan raya tahun 2009 adalah yang ketiga kali pada masa post-Soeharto. Pada pilihan raya kali ini jumlah wanita yang masuk menjadi ahli parlimen jauh meningkat berbanding dua pilihan raya sebelumnya (1999 dan 2004). Pada tahun 1999 seramai 42 orang dan tahun 2004 seramai 62 orang yang terpilih maka pada tahun 2009 seramai 103 orang yang terpilih. Angka ini cukup menggembirakan dari 9.09 peratus (1999), 11.27 peratus (2004) menjadi 17.86 peratus (2009). Peningkatan jumlah ini tentu saja belum mencapai 30 peratus sebagai minimum angka yang menjadi harapan.

Profil latar belakang wanita yang terpilih pada pilihan raya tahun 2009 ini meliputi pendidikan, pekerjaan, umur, riwayat keluarga dan hubungan dengan elite politik. Hasil kajian Puskapol FISIP UI (Puskapol FISIP UI 2013) menemukan 47,5 peratus pendidikan sarjana, 47 peratus pra-siswazah, 2,9 peratus sekolah menengah dan 0,9 peratus lulus diploma. Sementara ada 3 orang yang tidak dapat dikenali latar belakang pendidikannya. Pekerjaan wanita yang terpilih pada tahun 2009 ini beragam mulai dari peguam, dokter, pegawai kerajaan dan swasta. Ada juga ibu suri rumah dan mantan artis (penyanyi dan pelakon).

Deretan umur wanita ini juga beragam mulai dari 21 tahun sampai kepada 65 tahun. Bilangan terbanyak adalah umur 36 sampai 50 tahun seramai 49 orang (47,5\%), terbanyak kedua adalah umur 51-65 tahun seramai 29 orang $(28,1 \%)$ dan lainnya umur 21-35 tahun.

Bilangan 103 wanita yang terpilih pada pilihan raya tahun 2009 ini yang pernah menjadi ahli parlimen (DPR, DPD, DPRD dan MPR) adalah 29 peratus manakala 71 peratus belum pernah menjadi ahli parlimen. Dapatan kajian ini pula menjelaskan dari 103 wanita ada 27 orang (26\%) yang mempunyai hubungan dengan "elit politik". Yang dimaksud "elit politik" adalah pengurusi utama parti, mempunyai jawatan kuasa di kerajaan pusat mahupun daerah seperti Menteri kabinet, Gubernur, Bupati mahupun Walikota.

Ada perubahan dari tindakan afirmasi dalam peningkatan jumlah wanita untuk menjadi calon dan peluang wanita terpilih melalui polisi Undang-undang nombor 31 tahun 2002 dan Undang-undang nombor 12 tahun 2003 kepada Undang-undang nombor 2 tahun 2008 Undang-undang nombor 10 tahun 2008. Puskapol FISIP UI ilustrasikan perubahan penting dari polisi seperti jadual berikut: 
DOI: https://doi.org/10.47405/mjssh.v5i1.350

Jadual 4: Jadual Polisi Afirmasi Pilihan Raya tahun 2004 dan 2009

\begin{tabular}{|c|c|c|c|}
\hline No & Undang-undang dan isu & Pilihan Raya 2004 & Pilihan Raya 2009 \\
\hline \multicolumn{4}{|c|}{ Undang-undang Parti Politik } \\
\hline 1 & $\begin{array}{l}\text { Fungsi rekrutment } \\
\text { (pengambilan calon) }\end{array}$ & $\begin{array}{l}\text { Memperhatikan kesetaraan } \\
\text { (equity) dan keadilan } \\
\text { (equality) gender }\end{array}$ & $\begin{array}{l}\text { Memperhatikan kesetaraan } \\
\text { (equity) dan keadilan } \\
\text { (equality) gender }\end{array}$ \\
\hline 2 & $\begin{array}{l}\text { Kepengurusan } \\
\text { (Pengurusi) }\end{array}$ & $\begin{array}{l}\text { Memperhatikan } \\
\text { keterwakilan perempuan }\end{array}$ & $\begin{array}{l}\text { Menyertakan sedikitnya } 30 \% \\
\text { perempuan. }\end{array}$ \\
\hline \multicolumn{4}{|c|}{ Undang-Undang Pemilu (Pilihan Raya) } \\
\hline 1 & Daerah Pemilihan & $\begin{array}{l}\text { DPR: } 3-12 \text { kerusi } \\
\text { DPRD: } 3-12 \text { kerusi }\end{array}$ & $\begin{array}{l}\text { DPR: } 3-10 \text { kerusi } \\
\text { DPRD: } 3-12 \text { kerusi }\end{array}$ \\
\hline 2 & Kaedah Pencalonan & $\begin{array}{l}\text { Memperhatikan } \\
\text { keterwakilan perempuan } \\
\text { minimum } 30 \% \text { dalam } \\
\text { pencalonan legislatif }\end{array}$ & $\begin{array}{l}\text { Daftar calon memuat } 30 \% \\
\text { calon perempuan; setiap tiga } \\
\text { calon minimum satu wanita. }\end{array}$ \\
\hline 3 & Kaedah Pemberian Suara & $\begin{array}{l}\text { Parti dan calon, atau partai } \\
\text { sahaja }\end{array}$ & Parti atau calon \\
\hline 4 & Perumusan Calon Terpilih & $\begin{array}{l}100 \% \text { BPP (Bilangan } \\
\text { Pembagi Pemilih) + nomor } \\
\text { urut }\end{array}$ & $\begin{array}{l}30 \% \text { BPP + nomor urut } \\
\text { (diganti perumusan suara } \\
\text { terbanyak oleh keputusan } \\
\text { Mahkamah Konstitusi pada } \\
\text { 26hb Dec } 2008 \text {. }\end{array}$ \\
\hline
\end{tabular}

Sumber: (Puskapol FISIP UI 2013:18)

Kesan dari pada polisi tersebut adalah peningkatan pada bilangan calon wanita dalam pilihan raya dari tahun 2004 ke tahun 2009. Maknanya semakin banyak bilangan wanita menjadi calon maka semakin besar peluang wanita untuk terpilih menjadi ahli parlimen wanita.

Pusat Kajian Politik Universitas Indonesia (Puskapol UI) menyoroti juga nombor urut kecil wanita pada dalam daftar calon. Dapatan hasil kajian Puskapol UI memperlihatkan korelasi positif antara nombor kecil dengan wanita terpilih. Bilangan wanita yang menjadi calon pula meningkat dari pilihan raya 2004 ke 2009 seperti tergambar dalam jadual V berikut ini:

Jadual 5: Perbandingan Calon Ahli Parlimen dan Calon Ahli Wanita Terpilih Pada Pilihan Raya Tahun 2004 dan 2009.

\begin{tabular}{llll}
\hline No & Penjelasan & Pilihan Raya 2004 & Pilihan Raya 2009 \\
\hline 1 & Bilangan calon ahli parlimen wanita & 2,507 & 3,910 \\
2 & Peratusan calon ahli parlimen wanita & $33 \%$ & $34,7 \%$ \\
3 & Bilangan calon ahli parlimen wanita terpilih & 61 & 103 \\
4 & Peratusan calon ahli parlimen wanita terpilih & $11,09 \%$ & $17,86 \%$ \\
\hline
\end{tabular}

Sumber: Puskapol FISIP UI 2013:19

Peningkatan jumlah wanita terpilih dari seramai 62 kepada 103 wanita, secara peratus meningkat meskipun belum banyak. Secara keseluruhan dari 560 ahli parlimen bilangan wanita adalah 18\% manakala ahli parlimen lelaki adalah $82 \%$.

Ada beberapa isu penting yang menjadi sorotan dalam pilihan raya tahun 2009 iaitu parti politik, nombor kecil dan daerah pemilihan (kawasan undi). Parti politik sebagai organisasi rasmi yang boleh 
mencalonkan mempunyai polisi sendiri dalam menempatkan wanita sama ada untuk nombor kecil mahupun kawasan undi. Polisi kerajaan melalui Undang-undang No.10 tahun 2008 seksyen 53 yang memberi cadangan kepada parti politik untuk menetapkan calon minimum 30\% dalam setiap kawasan undi dapat dipenuhi oleh banyak parti, meskipun ada beberapa parti yang tidak mencukupi $30 \%$ itu. Parti yang tidak mencukupi 30 peratus adalah Parti Amanat Nasional (PAN), Parti Persatuan Pembangunan (PPP) dan Parti Gerindra. Jadual berikut adalah jadual parti politik yang calonnya masuk parlimen pada pilihan raya tahun 2009.

Jadual 6: Bilangan Calon Ahli Parlimen Terpilih dari Parti Politik Pilihan Raya Tahun 2009

\begin{tabular}{lllll}
\hline No & Parti & Total Kerusi & Kerusi Wanita & Wanita (\%) \\
\hline 1 & Demokrat & 149 & 35 & $(23,5 \%)$ \\
2 & Golkar & 106 & 19 & $(17,9 \%)$ \\
3 & PDIP & 94 & 18 & $(19,1 \%)$ \\
4 & PKS & 57 & 3 & $(5,3 \%)$ \\
5 & PAN & 46 & 7 & $(15,2 \%)$ \\
6 & PPP & 38 & 5 & $(13,2 \%)$ \\
7 & PKB & 28 & 7 & $(25 \%)$ \\
8 & Gerindra & 26 & 5 & $(19.2 \%)$ \\
9 & Hanura & 16 & 4 & $(25 \%)$ \\
Jumlah & 560 & 103 & $18 \%$ \\
\hline
\end{tabular}

Sumber: (Puskapol FISIP UI 2015:7) dan (Margret at al. 2018: 23)

Berkenaan dengan jadual di atas parti Demokrat memperolehi peningkatan dengan ketara bilangan kerusi wanita dari tahun 2004 ke tahun 2009. Parti besar dan parti lama seperti Golkar dan PDIP juga masih memperolehi bilangan wanita yang lebih banyak berbanding parti lainnya.

Isu kedua yang menjadi sorotan dalam keterpilihan wanita pada pilihan raya tahun 2009 adalah nombor sebilangan kecil. Trend data yang dianalisis oleh Puskapol FISIP UI pada isu nombor menyatakan bahawa terpilihnya wanita meningkat apabila parti mencalonkan wanita dalam jumlah yang banyak (30\% atau lebih) dan ditempatkan pada nombor kecil dalam senarai calon, maka peluang wanita terpilih semakin besar. Analisis data dari jumlah wanita terpilih hasil pilihan raya tahun 2009 menjelaskan nombor sebilangan kecil iaitu : nombor satu ada 44 peratus $(44 \%)$, nombor dua ada 29 peratus $(29 \%)$, nombor tiga ada 20 peratus $(20 \%)$ sedangkan nombor empat dan berikutnya ada 7 peratus (7\%). Trend ini juga berlaku kepada calon lelaki yang terpilih menjadi ahli parlimen. Meskipun sistem pemenang undi terbanyak yang dipilih namun nombor kecil dalam senarai nama calon tetap penting.

Isu ketiga yang menjadi perhatian adalah kawasan asal tempat undi di mana wanita menjadi calon. Ada 77 tempat undi berasaskan pada hitungan bilangan penduduk dan jumlah kerusi bermula daripada 3-10 kerusi di setiap kawasan undi. Ada trend kecenderungan yang berlaku pada kawasan undi dengan bilangan kerusi kecil wanita dapat memperolehi kerusi pada pilihan raya tahun 2009. Trend bilangan wanita terpilih pada kawasan pilihan dengan kerusi bilangan kecil lebih tinggi berbanding sebaliknya pada pilihan raya tahun 2004 .

\section{Pilihan Raya Tahun 2014 (9 April 2014)}

Tahun 2014 adalah kali ke-empat pilihan raya era demokrasi. Pada aspek undang-undang terus mengalami kemajuan dalam rangka mendorong wanita masuk parlimen. Dinamik perubahan dalam Undang-undang dapat dilihat pada jadual berikut; 
DOI: https://doi.org/10.47405/mjssh.v5i1.350

Jadual 7: Dinamik "Polisi Afirmasi” dalam pilihan raya 2004-2019

\begin{tabular}{llll}
\hline Pilihan Raya 2004 & Pilihan Raya 2009 & Pilihan Raya 2014 & Pilihan Raya 2019 \\
\hline UU Pemilu & UU Pemilu & UU Pemilu & UU Pemilu \\
No.12/2003: calon & No.10/2008; daftar & No.8/2012: & No.7/2017; sama \\
anggota DPR RI, & calon yang diajukan & ketentuan yang & dengan ketentuan \\
DPRD Provinsi dan & parpol memuat 30\% & sama dengan UU & UU Pemilu \\
DPRD Kab/Kota & perempuan dan & No.10/2008 & No.8/2012 \\
dengan & penempatannya & diperkuat dengan & \\
memperhatikan & minimal satu & PKPU (Peraturan & \\
keterwakilan & perempuan dalam & Komisi Pemilihan & \\
perempuan 30\% & setiap 3 (tiga) nama & Umum) No.7/2013 & \\
& calon. & yang mewajibkan & \\
& & pencalonan & \\
& & perempuan & \\
& & sebagaimana diatur & \\
& & dalam UU harus & dilakukan di setiap \\
& & daerah pemilihan. & \\
& & & \\
& & &
\end{tabular}

Sumber: (Margret et al. 2018: 19-20)

Selain daripada Undang-undang ada peraturan tambahan dari Komisi Pemilihan Umum (KPU) No.7 tahun 2013 yang mengatur tentang pencalonan wanita. Apabila dalam satu kawasan undi (daerah pemilihan) wanita yang dicalonkan kurang dari 30\% (tiga puluh peratus) maka hukumannya adalah Parti itu tidak dapat ikut pilihan raya pada kawasan undi terbabit. Jika pilihan raya tahun 2009 masih ada parti yang mencalonkan kurang dari 30\% (tiga puluh peratus), maka pilihan raya tahun 2014 tidak ada lagi. Jumlah peratusan dalam pencalonan wanita pada pilihan raya 2014 meningkat dari pilihan raya tahun 2009. Parti PKS paling tinggi peratusan dalam pilihan raya tahun 2009 iatu 36,61 \% (tiga puluh enam peratus) dan pada pilihan raya tahun 2014 parti PKS tertinggi urut ke-3 setelah Parti Nasdem (40,43\%) dan parti PPP (39,5\%).

Ada 12 parti yang ikut dalam persaingan merebut kerusi 560 kerusi parlimen tahun 2014, parti yang lolos dari peraturan "parliamentary threshold" (ambang parlimen) adalah 10 parti. Peraturan ambang parlimen adalah bagi parti yang ikut bertanding mesti mencapai minimum undi total $4 \%$ (empat peratus) undi untuk masuk parlimen, jika tidak mencapai maka parti tersebut tidak dapat wakil di parlimen. Nama-nama parti itu adalah: Golkar, PDIP, PPP, Gerindra, Demokrat, PAN, PKB, PKS, Nasdem, Hanura, PBB dan PKPI. PBB dan PKPI tidak lolos ambang batas parlimen. Pada jadual berikut dapat dilihat gambaran hasil pilihan raya tahun 2014 untuk wanita yang terpilih.

Jadual 8: Jumlah Kerusi Wanita dari Parti Politik DPR 2014-2019

\begin{tabular}{lllll}
\hline No & Parti Politik & Total Kerusi Parti & $\begin{array}{l}\text { Jumlah Kerusi } \\
\text { Wanita }\end{array}$ & $\begin{array}{l}\text { Peratus } \\
\text { Kerusi Wanita }\end{array}$ \\
\hline 1 & PDIP & 109 & 21 & $19 \%$ \\
2 & Golkar & 91 & 16 & $17 \%$ \\
3 & Gerindra & 73 & 11 & $15 \%$ \\
4 & Demokrat & 61 & 13 & $21 \%$ \\
5 & PAN & 49 & 9 & $18 \%$ \\
6 & PKB & 47 & 10 & $21 \%$ \\
7 & PKS & 40 & 1 & $3 \%$ \\
8 & PPP & 39 & 10 & $26 \%$ \\
9 & Nasdem & 35 & 4 & $11 \%$ \\
10 & Hanura & 16 & 2 & $12 \%$ \\
\multicolumn{2}{l}{ Jumlah } & 560 & 97 & $17 \%$ \\
\hline
\end{tabular}

Sumber: (Puskapol FISIP UI 2015: 6) 
Merujuk kepada data pilihan raya 2004, 2009 dan 2014 jumlah wanita yang terpilih mengalami penurunan pada tahun 2014. Pada masa penyelidikan ini dilakukan jumlah wanita yang duduk di parlimen bertambah menjadi 103 wanita yang menjadi ahli parlimen. Ini disebabkan oleh pergantian antar waktu (PAW) dari ahli parlimen yang berhalangan. Mereka yang berhalangan kerana masuk dalam posisi jabatan Negara "Eksekutif" (menteri Kabinet, Duta besar, Gubernur, Bupati dan Walikota), ada yang meninggal dan ada juga kerana kasus rasuah. Jumlah wanita bertambah kerana ini namun ada juga yang berkurang wanita dari parti Hanura yang terpilih keduanya kena kasus rasuah.

Perbandingan dapatan kerusi wanita pada parti pada dua pilihan raya tahun 2009 dan 2014 terdapat kerusi yang naik namun ada pula yang turun. Puskapol FISIP UI (2015) mencatat dari 9 (Sembilan) parti yang masuk parlimen tahun 2009 ada 5 (Lima) parti yang naik dan 4 (empat) parti yang turun jumlah wanita parlemen. Parti yang naik jumlah wanitanya adalah PDIP, Gerindra, PKB, PAN dan PPP, sedangkan yang turun adalah Demokrat, Golkar, PKS dan Hanura.

Ada beberapa fakta menarik dalam pembacaan angka jumlah pencalonan dan keterpilihan wanita jika dibandingkan pada 2 (dua) pilihan raya 2009 dan 2014. Jadual berikut adalah gambarannya dari 10 parti yang ikut bertanding pada pilihan raya tahun 2009 dan 2004 kecuali parti Nasdem.

Jadual 9: Perbandingan Jumlah Calon dan Keterpilihan Wanita pada Pilihan Raya 2009 dan 20014

\begin{tabular}{llllll}
\hline \multirow{2}{*}{ No } & Parti Politik & \multicolumn{2}{c}{ Pilihan Raya 2009 } & \multicolumn{2}{l}{ Pilihan Raya 2014 } \\
\cline { 3 - 6 } & & Calon & Terpilih & Calon & Terpilih \\
\hline 1 & PDIP & 222 & 18 & 200 & 21 \\
2 & Golkar & 194 & 19 & 202 & 16 \\
3 & Gerindra & 116 & 5 & 203 & 11 \\
4 & Demokrat & 221 & 35 & 205 & 13 \\
5 & PAN & 177 & 7 & 207 & 9 \\
6 & PKB & 134 & 7 & 210 & 10 \\
7 & PKS & 212 & 3 & 191 & 1 \\
8 & PPP & 127 & 5 & 214 & 10 \\
9 & Hanura & 186 & 4 & 203 & 2 \\
10 & Nasdem & - & - & 226 & 4 \\
\hline
\end{tabular}

Sumber: (diolah dari Puskapol FISIP UI 2013 dan 2015)

Melihat pada data tersebut di atas sulit mendapatkan penjelasan hubungan antara pencalonan dan keterpilihan pada dua pilihan raya tersebut. Perhitungan logik seharusnya semangkin banyak calon wanita seharusnya semakin besar pula peluang terpilih. Penjelasan terhadap fakta ini adalah ada banyak faktor yang terjadi dalam proses politik ini. Masuknya wanita dalam politik bukan sekedar angka dalam senarai calon sebagaimana disyaratkan oleh Undang-undang, tapi banyak faktor yang mesti dipertimbangkan. Kajian Puskapol FISIP UI (2015: 7-8) mendapatkan ada beberapa isu yang menjadi sorotan dalam pilihan raya tahun 2014 ini adalah terpilih kembali (incumbent), latar belakang elit ekonomi dan jaringan keluarga dengan elit politik.

Isu incumbent dapat dilihat dari 550 (lima ratus lima puluh) ahli parlimen 242 (dua ratus empat puluh dua) atau $43.2 \%$ (peratus) orang adalah "incumbent" laki-laki sebanyak 203 (dua ratus tiga) atau 84\% orang dan wanita 39 (tiga puluh sembilan) atau $40.21 \%$ (peratus) orang. Data ini menyatakan bahwa wajah baru di parlimen lebih besar daripada wajah lama iaitu $60 \%$ berbanding $40 \%$. Pengalaman wanita yang mengikuti beberapa pilihan raya seperti Meutya Hafidz, Melani Suharli dan Diah Pitaloka mengatakan bahwa masyarakat sudah sangat "materialistis", jika calon datang mereka menghubungkan dengan bagi-bagi wang. (Puskapol FISIP UI 2015). Selari dengan hasil temu bual antara penulis dan informan tentang pengalaman mereka di masyarakat pada pilihan raya tahun 2009 dan 2014. 
DOI: https://doi.org/10.47405/mjssh.v5i1.350

Berikutnya ada $15 \%$ (peratus) yang berasal daripada ahli parlimen tingkat DPRD (Provinsi) dan DPD (Dewan Perwakilan Daerah). Mereka yang pernah di legislatif ini mayoriti juga adalah lak-laki. Mereka yang berasal dari legislatif sebelumnya adalah bernilai positif untuk sistim kader parti kerana mereka mempunyai "basis massa" yang nyata di masyarakat, namun angka ini hanya mencapai $15 \%$ sahaja dan wanita seramai 14 orang dari total 550 kerusi. Mereka yang masuk DPR RI berasal dari DPRD sebelumnya adalah My Esty dari Jogjakarta dan Mercy dari Maluku adalah informan yang dipilih dan diajak temu bual.

Latar belakang "elit ekonomi" dalam pencalonan juga disorot oleh Soeseno (Soeseno 2014), berikut adalah jadual latar belakang pekerjaan calon wanita pada pilihan raya tahun 2014 .

Jadual 10: Latar belakang pekerjaan calon legislative wanita pilihan raya 2014

\begin{tabular}{llll}
\hline No & Pengelompokan Pekerjaan & Jumlah & Peratus \% \\
\hline 1 & Usahawan/swasta & 1032 & 41.9 \\
2 & Profesi khusus (Dokter, Peguam, Akademisi, Artis, Ustad) & 512 & 20.8 \\
3 & $\begin{array}{l}\text { Pensiunan pegawai (Syarikat Negara, Staf DPR, Staf Mentri } \\
\text { dll) }\end{array}$ & 202 & 8.2 \\
4 & Politisi (mantan DPR, DPRD dan DPD) & 117 & 7.2 \\
5 & Aktivist (jurnalis, NGOs, mahasiswa) & 81 & 3.3 \\
6 & Punya jawatan atau mantan di kerajaan (menteri dan kepala & $9 / 10$ & 0.4 \\
& daerah) & 451 & 18.3 \\
7 & Lain-lain (suri rumah, tidak ada keterangan) & 2465 & 100 \\
\hline
\end{tabular}

Sumber: (Soeseno 2014:104)

Berdasarkan pada jadual di atas hasil pilihan raya yang memenangkan calon dengan latar belakang pekerjaan "elit ekonomi" lebih mendominasi. Isu politik uang lebih mengemuka pada pilihan raya tahun 2014 berbanding pilihan raya sebelumnya (Pukapol FISIP UI 2014:40). Hasil temu bual penulis dengan 29 (dua puluh Sembilan) wanita yang menjadi informan mengatakan perlu "modal" (wang) yang lumayan dalam kempen agar menang.

Isu ada hubungan kekerabatan dengan "elit politik" juga mengemuka dalam faktor keterpilihan wanita untuk parlimen. Puskapol FISIP UI menyebutnya "jaringan kekerabatan" sementara Nuri (2014) menyebutnya "perempuan politisi dari dinasti politik". Dari 96 (Sembilan puluh enam) wanita yang terpilih ada 36 (tiga puluh enam) orang atau $47 \%$ yang dapat dikenal pasti pada masing-masing parti. Setiap parti ada kecuali parti PKS dan Hanura (Puskapol FISIP UI 2015: 41). Menurut penulis sendiri adalah wanita dalam jaringan "nepotisme". Mereka ini ada yang mempunyai hubungan saudara dengan "elit politik" namun ada juga yang mempunyai hubungan berkawan lama.

Pada tahun 2019 diadakan pilihan raya yang berbeza daripada sebelumnya untuk mengundi ahli parlimen sahaja, pada tahun ini juga mengundi untuk presiden dan timbalan presiden.

\section{Pilihan Raya tahun 2019 (17 April 2019)}

Pilihan raya tahun 2019 menghasilkan jumlah wanita yang masuk parlimen meningkat berbanding tahun 2014 dari tujuh belas pin enam $(17,6 \%)$ sembilan belas poin empat lapan peratus $(19,48 \%)$. Komisi Pemilihan Umum (KPU) sebagai suruhanjaya pilihan raya di Indonesia membuat ringkasan data ahli parlimen 2019.

Merujuk pada gambar di bawah ini dari 575 orang ahli parlimen untuk tempoh 2019-2024 jumlah lelaki yang lolos ke parlimen ada 463 orang manakala wanita ada 112 orang. Latar belakang pendidikan paling ramai adalah sarjana dan master, masih ada yang lulus sekolah menengah dalam sembilan poin tujuh peratus $(9,7 \%)$. Banjaran umur yang paling dominan adalah di antara 41-60 tahun $(66,78 \%)$, untuk umur di atas dan di bawahnya adalah sama dalam peratus. Calon "incumbent" penyandang jawatan iaitu mereka yang sebelumnya menjadi ahli parlimen dengan mereka yang baru 
DOI: https://doi.org/10.47405/mjssh.v5i1.350

terpilih adalah hampir sama dalam peratus. Ada 289 orang (50,26\%) dan wajah baru adalah 286 orang $(49,74 \%)$.

Gambar 1: Iktisar Jumlah Calon Pilihan Raya 2019:

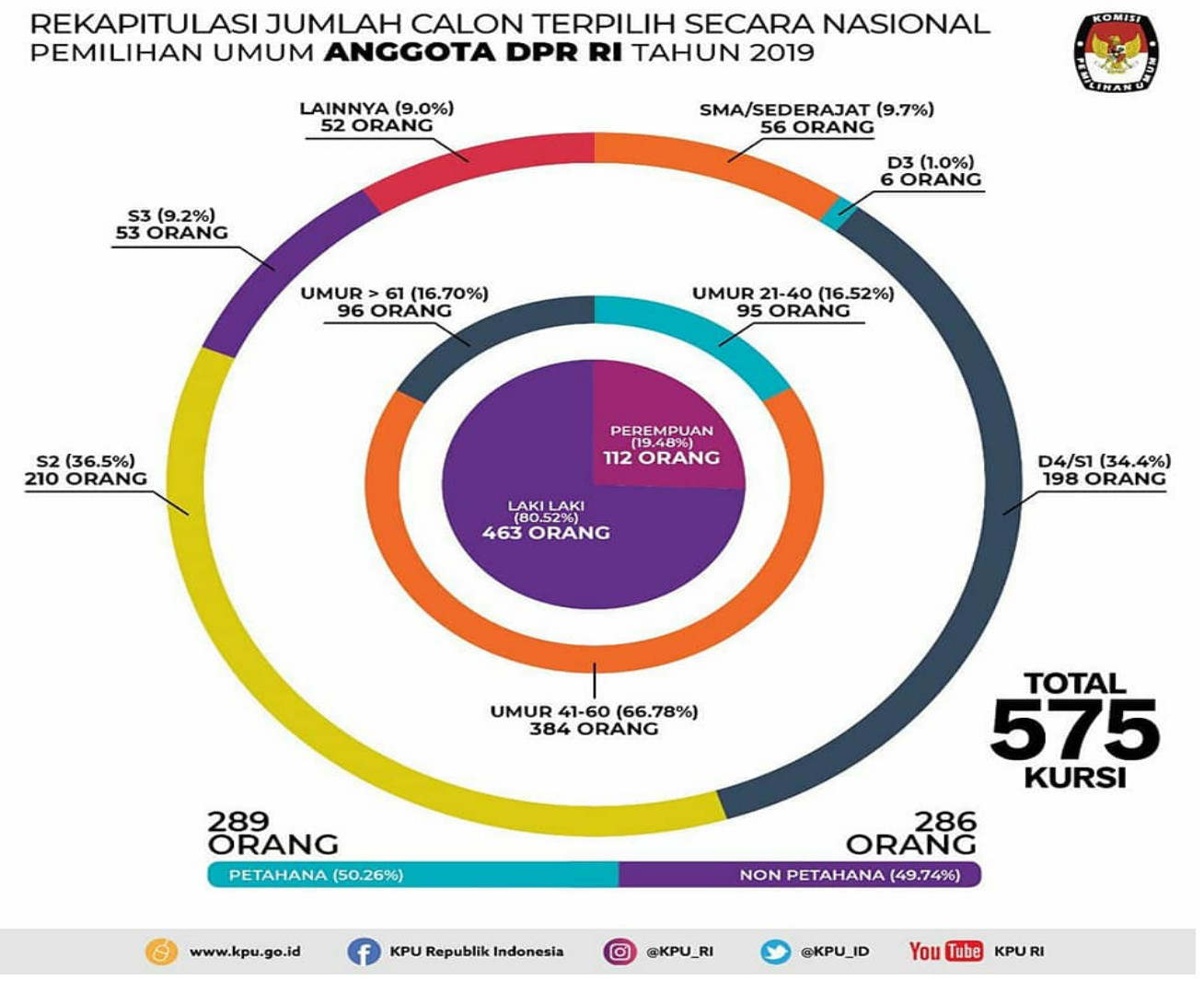

Sumber: https://infopemilu.kpu.go.id/pileg2019

Gambar berikut adalah penjelasan tentang latar belakang pekerjaan ahli parlimen 2019 adalah sebagai "legislator" atau penyandang jawatan (incumbents) ahli DPR 2014-2019 seramai 289 orang (50,26\%). Ada 36 orang yang menjadi ahli legislatif tingkat DPD, DPRD Provinsi dan Kota sebelumnya. Pekerjaan sebagai usahawan atau profesional mendapat tempat kedua untuk latar belakang pekerjaan iaitu 189 orang $(32,86 \%)$. Latar belakang pekerjaan lainnya seperti pegawai kerajaan ada 20 orang $(3,48 \%)$, pencen $15(2,6 \%)$ orang dan "kepala daerah" (Gabenur, Datuk Bandar) seramai 13 orang $(2,26 \%)$. 
Gambar 2: Ikhtisar Latar Belakang Pekerjaan Ahli Parlimen 2019-2024.

\section{REKAPITULASI JUMLAH \\ CALON TERPILIH SECARA NASIONAL \\ PEMILIHAN UMUM ANGGOTA DPR RI TAHUN 2019 \\ BERDASARKAN}

\begin{tabular}{|c|c|}
\hline 289 & ANGCOTA DPR/MPR 2014-2019 \\
\hline 2 | & ANGGOTA DPD/MPR 2014-2019 \\
\hline 26 & ANGCOTA DPRD PROVINSI 2014-2019 \\
\hline 4 & ANCGOTA DPRD KAB/KOTA 2014-2019 \\
\hline 189 & SWASTA/WIRASWASTA/PROFESIONAL \\
\hline 5 & MENTERI/PEJABAT SETINGKAT MENTERI \\
\hline 20 & APARATUR SIPIL NEGARA (ASN) \\
\hline 1 & PEJABAT/KARYAWAN BUMN \\
\hline 15 & PENSIUNAN \\
\hline 5 & IBU RUMAH TANGGA \\
\hline 4 & MAHASISWA \\
\hline 1 & USTADZ/MUBALIGH \\
\hline 13 & KEPALA DAERAH \\
\hline 11 & LAINNYA \\
\hline
\end{tabular}

TOTAL 575

(3) www.kpu.go.id ff KPU Republik Indonesia (ㅇ) बKPU_RI () बKPU_ID Yoll tuble KPURI

Sumber: https://infopemilu.kpu.go.id/pileg2019

\section{Perbincangan}

Merujuk pada data dinamik wanita yang menjadi ahli parlimen, perlu melihat konteks di mana sistem kerajaan dan budaya yang dibangun oleh setiap rezim. Sundari (Sundari 2014) melihat bahwa perjalanan wanita masuk arena politik dipengaruhi oleh faktor rezim yang berkuasa selain faktor budaya. Pada masa "Orde Lama" wanita banyak terlibat langsung dalam keputusan politik dan pengorganisasian seperti Wanita Muslimat NU, Gerwani, KOWANI dan Aisyiah. Pada masa "Orde Baru" yang dimulai tahun 1965 wanita dibelenggu dan didomestifikasi (wanita urus keluarga) dalam ruang "otoriterisme".

Liddle (Liddle 1992:453) berpendapat tentang Orde Baru yang bertindak balas terhadap cabaran dengan perubahan dalam dasar yang substantif sambil mengekalkan struktur autoritarian utuh. Konstruksi wanita pada masa "Orde Baru" dimana kerajaan (state ) dalam posisi sentral dan memanipulasi idiologi gender dengan memasukkan unsur "perumah tanggaan" dan ibuisme (uryakusuma (Suryakusuma 2011). Proses "ibuism" yang dilakukan oleh kerajaan masa "Orde Baru" yang tercermin dalam program Pembinaan Kesejahteraan Keluarga (PKK) yang digerakkan oleh Dharma Wanita (isteri daripada pegawai kerajaan), Bhayangkari (Isteri daripada Polis) dan Persit Kartika Chandra (Isteri daripada Tentera). Serangkaian program Negara seperti Keluarga Berencana (KB) digerakkan melalui organisasi tersebut tanpa pamrih. Wanita dalam kendali kuasa kerajaan melalui pegawai kerajaan, polis dan tentera. Jika suami mempunyai jawatan kuasa maka isteri dalam organisasi wanita punya jawatan sesuai dengan struktur suami. Nama aseli sudah ditukar dengan nama suami atau ditambah nama suami di belakang nama wanita tersebut. 
Pendekatan kekuasaan ini melumpuhkan tradisi kepemimpinan wanita yang terus menerus diterapkan "bapak-ibuism", yakni bapak atau lelaki dianggap sebagai pemimpin dan sumber kekuasaan, sementara ibu sebagai perempuan mediator dari kekuasaan tersebut. Wanita yang menjadi mediator ini adalah sebagai symbol "priyayisasi" iatu penggunaan nilai-nilai tradisional Jawa untuk kepentingan pembangunan dan modernitas yang dibungkus gaya militer (Sundari 2014).

Pilihan raya pada masa kepemipin Presiden Soeharto banyak melibatkan wanita yang ada hubungannya dengan "elite kekuasaan". Para isteri kepada menteri kabinet, istri Gabenur sampai istri Bupati (Datuk Bandar) ikut serta dalam memenangkan Golkar sebagai alat untuk mendapatkan kekuasaan. Sejak pilihan raya 1971 (pilihan raya kedua masa Soeharto sebagai presiden) wanita dalam lingkar kekuasaan mulai diturunkan ke padang politik untuk mengekalkan kekuasaan "Orde Baru". Peranan wanita dalam pilihan raya selain daripada ikut kempen mereka juga boleh mendapatkan kerusi parlimen. Penyertaan wanita dalam politik pada masa "Orde Baru" adalah karena status "istri" daripada suami yang mempunyai kuasa atau berada dalam "elit kuasa".

Presiden Soeharto yang berkuasa selama 32 tahun menanamkan nilai-nilai "kewanitaan" sangat dalam dan kuat. Untuk mengubah nilai dan pandangan tersebut sangat diperlukan strategi dan pendekatan menyeluruh. Mulai dari mengubal Undang-undang Dasar, peraturan dan polisi yang berkaitan dengan "diskriminasi gender" menjadi "berkeadilan gender". Pengarusutama (gender mainstreaming) dan sosialisasi "keadilan gender" mulai dilaksanakan manakala Indonesia memasuki era perubahan postSoeharto.

Kondisi sosial politik mempengaruhi dinamik relasi gender dan mampu mengubah, mentransformasi atau melanggengkan relasi gender yang timpang. Dengan kata lain, kesedaran tentang relasi kuasa yang timpang yang dimulai dari ranah peribadi dan di ruang domestik tersebut saling menjalin dengan struktur sosial politik yang berjalan. Politik pun harus dimaknai tidak bekerja dalam ruang yang hampa, melainkan dalam struktur relasi kuasa yang dinamik dan memiliki konteks historis. (Soejipto dalam Margret, et al. 2018).

Warisan sejarah terutama masa "Orde Baru" dalam memberi ruang kepada wanita masuk dalam politik tidak boleh hilang dalam tempoh singkat. Pemerkasaan (empowerment) menjadi alat untuk mencapai ketertinggalan wanita dalam politik parlimen. Gagasan "Affirmative action" sebagai bahagian dari upaya pemerkasaan melalui Undang-undang nampaknya memberi pengaruh pada sistem politik dan penyertaan wanita dalam politik parlimen. Penyertaan wanita dalam politik parlimen dimulai dari kehadirannya di parti. Parti politik merekrut ahli sebagai kader kemudian menjadi calon. Untuk menjadi calon ada mekanisma yang harus dilalui sesuai dengan peraturan organisasi parti. Namun begitu banyak parti yang menempuh cara lain selain daripada pencalonan kader. Menjadi "elite" di dalam parti dapat melalui cara sebagai orang yang "terkenal" (artis, pemain sukan dll), punya kuasa di daerah (Gubernur, Bupati, Walikota) dan bagian dari "dynasty elite politik". Oleh kerana itu kehadiran wanita sebagai "elit politik" berpengaruh terhadap pencalonan dan peluang keterpilihan (Puskapol FISIP UI 2015, Soeseno 2014, Kunovich \& Paxton 2005).

Isu lain yang juga mengemuka pada keterpilihan wanita adalah nombor urut pada pencalonan. Nombor urut 1 mahupun bilangan kecil menjadi isu penting dalam pencalonan kerana berdasarkan pada data hasil pilihan raya tahun 2004 wanita yang terpilih sebanyak $47.4 \%$ (empat puluh tujuh titik empat peratus) adalah nombor 1 (satu). Nombor urut 2 (dua) sebanyak $21.7 \%$ (dua puluh satu titik tujuh peratus). Nombor urut 3 (tiga) sebanyak $15.5 \%$ (Lima belas titik Lima), nombor 4 (empat) $1 \%$ (satu peratus), nombor 5 (Lima) $4.1 \%$ (empat titik satu peratus) dan nombor 6 (enam) sampai 10 (sepuluh) adalah $10.3 \%$ (sepuluh titik tiga peratus).

Pentingnya nombor urut 1 (satu) mahupun nombor kecil pernah menjadi materi gugatan ke Mahkamah Konstitusi pada Undang-undang Pilihan Raya Nombor 12 tahun 2003. Sistim penentuan dan penetapan satu kerusi merugikan banyak pihak termasuk wanita. Mereka yang nombor bawah mendapat hasil undi banyak (tapi tidak mencukupi bilangan 1 kerusi) maka semua hasil undi digabungkan kemudian diberikan kepada calon nombor 1 (satu). 
Penjelasan faktor "struktur" dari pada data angka yang muncul pada pilihan raya dan temuan Puskapol UI, Margret dan Soeseno (Margret et al 2018), FISIP UI 2015) dan Soeseno 2014) adalah latar belakang pendidikan wanita dan mempunyai "modal" cukup wang yang lumayan untuk kempen juga ikut memberikan kontribusi pada keterpilihan wanita. Kunovich dan Paxton (Kunovich \& Paxton 2005:513) menjelaskan:

"Structural explanations predict that women's educational achievements and women's participation in the labor force will positively affect women's levels of representation. Based in the observation that political elites are pulled disproportionately from the highly educated and from certain professions such as law (Putnam 1976), structural explanations argue that women need human and financial capital (gained through educational and work experience) to stand for office. It follows that the percentage of women who are economically active and who are highly educated should influence political outcomes for women, such as the percentage of female candidates in a country".

"Penjelasan "struktur" meramalkan bahawa pencapaian pendidikan wanita dan penyertaan wanita dalam tenaga kerja akan memberi kesan positif kepada tahap perwakilan wanita. Berdasarkan pemerhatian bahawa elit politik ditarik tidak seimbang dari yang berpendidikan dan dari profesi tertentu seperti undang-undang (Putnam 1976), penjelasan struktur berpendapat bahwa perempuan memerlukan modal manusia dan kewangan (diperoleh melalui pengalaman pendidikan dan kerja) untuk bertugas. Ini berikutan peratusan wanita yang aktif secara ekonomi dan yang berpendidikan tinggi harus mempengaruhi hasil politik bagi wanita, seperti peratusan calon perempuan di negara".

Dapatan lain kajian ini dengan merujuk kepada angka yang ditampilkan pada pilihan raya tahun 1999, 2004, 2009 dan 2014 penulis berpendapat ada hubungan antara perilaku masyarakat yang memilih parti dan wanita dengan nilai-nilai yang berlaku di masyarakat. Parti Nasionalis (bukan Islam) selalu mendapatkan kerusi lebih banyak sama ada hasil undi untuk parti mahupun hasil undi untuk wanita.

Kajian Mujani \& Liddle (Mujani and Liddle 2009) pada selepas satu dekad demokrasi di Indonesia tentang parti politik "sekular" menguasai majoriti penduduk Indonesia. Penjelasan pada corak sejarah "pluralisme" agama adalah dasar polisi "Orde Baru" Presiden Soeharto. Tindak balas pada dasar tersebut adalah majoriti pengundi Islam moden manakala parti Islam yang menggerakkan pemilih untuk mengundi mereka kurang berkesan.

Temuan daripada data ini tentu saja memerlukan penyelidikan dan kajian lebih lanjut, namun temuan ini tidak dalam lingkup bahasan pada disertasi ini.

\section{Kesimpulan}

Penyertaan wanita dalam politik parlimen Post-Soeharto di Indonesia menunjukkan bilangan peningkatan. Warisan budaya tentang peranan wanita yang ditentukan pada masa pentadbiran Soeharto masih ada. Kajian Suryakusuma (2011) tentang "State-Ibuism" masih melekat, meskipun begitu kesedaran wanita untuk menyertai politik melalui pemerkasaan dapat dilihat pada terpilihnya wanita menjadi ahli parlimen. Antara mereka ada yang terpilih lima tempoh. Tindakan afirmasi melalui undang-undang untuk mencapai angka minimum 30 peratus dalam pencalonan ikut menyokong dalam menambah bilangan wanita menjadi ahli parlimen. Meskipun begitu ada beberapa catatan yang menjadi perhatian untuk diperbaiki iaitu system rekrut kader parti, kawasan pilihan dan sokongan parti untuk wanita yang tidak cukup modal dalam kempen.

\section{Rujukan}

Anggraini, Tuti. 2019. Peta Keterpilihan Perempuan di DPR RI pada Pemilu 2019. Data Perludem shared on FGD 22-23 August 2019 in LIPI Jakarta. 
DOI: https://doi.org/10.47405/mjssh.v5i1.350

Bessel, S. 2004. Women in Parliament in Indonesia: Denied a Share of Power. Canberra: Crawford School of Economics and Government, the Australian National University, Policy and Governance Discussion Paper: 04-07.

Bush, S. S. (2011). International Politics And The Spread Of Quotas For Women In Legislatures. International Organization, 65(1), 103-137.

Choi, N. (2018). Women's political pathways in Southeast Asia. International Feminist Journal of Politics, 21(2), 224-248.

Enright, E. (2016). Unraveling the Relationship Between Gender Inequality and Quota Failure (Doctoral dissertation).

Hillman, B. (2017a). Increasing Women's Parliamentary Representation In Asia And The Pacific: The Indonesian Experience. Asia \& The Pacific Policy Studies, 4(1), 38-49.

Hillman, B. (2017b). The Limits of Gender Quotas: Women's Parliamentary Representation in Indonesia. Journal of Contemporary Asia, 48(2), 322-338.

Kishwar, M. (1996). Women And Politics: Beyond Quotas. Economic And Political Weekly, 28672874.

Krook, M. L. (2005). Politicizing Representation: Campaigns For Candidate Gender Quotas Worldwide (Doctoral Dissertation, Columbia University).

Krook, M. L., \& Norris, P. (2014). Beyond Quotas: Strategies To Promote Gender Equality In Elected Office. Political Studies. 62(1): 2-20.

Krook, M. L. (2016). Contesting Gender Quotas: Dynamics of Resistance. Politics, Groups, and Identities. 4(2): 268-283.

Komisi Pemilihan Umum Indonesia. 2019. https://infopemilu.kpu.go.id/pileg2019

Kunovich, S. L., Paxton, P., \& Hughes, M. M. 2005. Pathways to Power; The Role of Political Parties in Women's National Political Representation. American Journal Of Sociology. 111 (2): 505-552.

Kurniawan, N. (2014). Keterwakilan Perempuan di Dewan Perwakilan Rakyat Pasca Putusan Mahkamah Konstitusi Nomor 22-24/PUU-VI/2008. Jurnal Konstitusi, 11(4), 714-736.

Liddle, R. W. 1992. Indonesia's Democratic Past and Future. Comparative Politics. 443-462.

Margreth, Anna. Yolanda Panjaitan., Mia Novita Sari,. dan Julia Ikasarana. 2018. Menyoal Data Representasi Perempuan di Lima Ranah. Cakra Wikara Indonesia, UI. Depok.

Mujani, S., \& Liddle, R. W. 2009. Muslim Indonesia's secular democracy. Asian Survey. 49 (4): $575-$ 590.

Prihatini, E. S. 2018. Women's Representation in Asian Parliaments: a QCA approach. Contemporary Politics, 25(2): 213-235.

Prihatini, E. S. 2019. Women's Views and Experiences of Accessing National Parliament: Evidence from Indonesia. In Women's Studies International Forum. 74; 84-90. Pergamon.

Puskapol FISIP UI. 2013. Potret Keterpilihan Perempuan di Legislatif Pada Pemilu 2009. FISIP UI Depok.

Puskapol FISIP UI dan Kementerian Pemberdayaan Perempuan dan Perlindungan Anak. 2015. Potret Keterpilihan Perempuan di Legislatif Pada Pemilu 2014. FISIP UI Depok.

Putnam, R. D. 1976. The Comparative Study of Political Elites (p. 96). Englewood Cliffs, NJ: Prentice-Hall.

Suryakusuma, Julia. 2011. Ibuisme Negara. Konstruksi Sosial Keperempuanan Orde Baru. Komunitas Bambu. Depok.

Sanit, Arbi. 1997. Partai, Pemilu dan Demokrasi. Pustaka Pelajar Jogjakarta.

Soeseno, N. 2014. Perempuan Politisi dalam Partai Politik Pemilu 2014: Keterwakilan Deskriptif vs Substantif. Jurnal Perempuan, Untuk Pencerahan dan Kesetaraan. 19 (2): 95-124.

Sundari, Any. 2014. Politik Berbasis Komunitas: Pemberdayaan Perempuan Pemimpin do Yogyakarta. Jurnal Perempuan, Untuk Pencerahan dan Kesetaraan. 19 (2): 127-139. 